\title{
The New Normativity: The Abuse Excuse and the Resurgence of Judgment in the Criminal Law
}

Victoria Nourse

Georgetown Law Center, vfn@law.georgetown.edu

Georgetown Public Law and Legal Theory Research Paper No. 12-105

This paper can be downloaded free of charge from:

https://scholarship.law.georgetown.edu/facpub/1012

http://ssrn.com/abstract=2115469

50 Stan. L. Rev. 1435-1470 (1998) (reviewing James Q. Wilson, Moral Judgment: Does the Abuse Threaten Our Legal System? (1997))

This open-access article is brought to you by the Georgetown Law Library. Posted with permission of the author. Follow this and additional works at: https://scholarship.law.georgetown.edu/facpub 


\title{
The New Normativity: The Abuse Excuse and the Resurgence of Judgment in the Criminal Law
}

\author{
Victoria Nourse*
}

\author{
MORAL Judgment: DOES THE ABUSE EXCUSE ThreAten OUR Legal \\ SYSTEM? By James Q. Wilson. ${ }^{\dagger}$ New York: HarperCollins. 1997. ix +134 \\ pp. $\$ 18.00$.
}

There is growing interest within the academy in reviving the "normative" in criminal law scholarship. Enter a recent book, Moral Judgment, by the distinguished criminologist James Q. Wilson. Professor Wilson's work prompts the question: What is meant by the term "judgment"? Considering three different models-judgment as community, judgment as character, and judgment as critique-this review argues that Professor Wilson's idea of judgment both departs from the "new normativity" in existing scholarship and shows how easily "judgment" may stand in for partial aims. Professor Wilson argues that the "abuse excuse" is the product of modern social movements that make some defendants, like battered women, more attractive "victims" than others. For these defendants, Wilson argues, the law seeks to explain rather than judge their behavior. Unfortunately, when one comes to look at the particular defenses that Wilson embraces as proper "judgments" and rejects as poor "explanations," Wilson's theory begins to raise serious questions. For example, although Wilson is particularly critical of battered women's claims, he leaves out important parallels to excuses typically raised by men under the rubric of a well-known and long-standing defense-provocation. This selectivity, the review argues, not only betrays Wilson's judgment as the embrace of tradition for tradition's sake, but also tells us something important about the "abuse excuse." It tells us that the danger to our criminal justice system does not lie in a particular set of modern excuses, nor modern social movements like feminism, but in a failed theory of excuse.

* Assistant Professor of Law, University of Wisconsin. This review would not have been written without the generous support of the University of Maryland School of Law and Dean Donald Gifford. Special thanks go to Jane Schacter for her comments on an early draft and to Rick Cudahy for listening, one more time, to the ideas presented here.

$\dagger$ James Collins Professor of Management and Public Policy, University of California at Los Angeles. 


\section{INTRODUCTION}

It is popular these days to write about a crumbling criminal justice system. ${ }^{1}$ Municipal judges, former prosecutors, and other observers have taken to the talk show circuit peddling horror stories and opining about the Simpson trial, the Menendez verdicts, or the Rodney King travesty. With only slightly more temperate themes, academics have slowly added to this growing volume of work, urging popular audiences to consider the triumph of politics and the flight of "common sense" from the criminal justice system. ${ }^{2}$ Read by lay as well as academic audiences, these works have not only fueled public fears, but also given us a new name for the danger-the "abuse excuse." 3 The question remains, however, whether all this talk of criminal justice doomsday is more symptom than diagnosis.

James Q. Wilson's Moral Judgment is at once a part of this wave of popular literature and an attempt to transcend standard accounts. Professor Wilson, a renowned social scientist, has more ambitious intellectual aims than the talk show circuit. He urges his readers to consider difficult conceptual distinctions between causation and responsibility, ${ }^{4}$ hard and soft science, ${ }^{5}$ and explanation and judgment. ${ }^{6}$ Indeed, Wilson is careful to reject some common misconceptions about his topic, acknowledging, for example, that "there is no avalanche" of new excuses burdening our courts nor is there evidence that judges and juries have suddenly gone soft on crime. ${ }^{8}$ The system is in trouble, asserts Wilson, but it is in trouble because of a variety of conceptual errors, all of which stem from a fundamental failure to distinguish social scientific explanation from moral judgment.

There are strong reasons to disagree with Wilson's account of the abuse excuse-in particular his cast of villains-but his attempt to search deeper than the standard accounts merits attention. This is particularly true given

1. See generally Marcia Clark With Teresa CARPENTER, Without a DOUBT (1997); Judge HAROLD J. ROTHWAX, GUILTY: THE COLLAPSE OF CRIMINAL JUSTICE (1996).

2. See, e.g., Alan M. Dershowitz, The Abuse EXCuSE AND Other COP-OUTS, SOB Stories, AND EVASIONS OF RESPONSIBILITY (1994); GEORGE P. FLETCHER, WITH JUSTICE FOR SOME: PROTECTING VICTIMS' RIGHTS IN CRIMINAL TRIALS (1995).

3. Professor Dershowitz first gave us this label. See DERSHOwITZ, supra note 2, at 3. Originally used to refer only to defenses premised on the defendant's suffering prior abuse, Wilson and others use the term "abuse excuse" to refer to "a range of implausible excuses." P. 2. As scholars have noted, the term has appeared with "increasing prominence ... in ordinary social discourse, pop psychology, [and] the mass media." Stephen J. Schulhofer, The Trouble with Trials; The Trouble with Us, 105 YALE L.J. 825, 850 (1995) (reviewing FLETCHER, supra note 2).

4. See pp. 38-43.

5. See pp. 13-16.

6. See pp. 7, 90-91, 109-12.

7. P. 89.

8. See pp. 2-4. 
Wilson's focus on the concept of moral judgment. Criminal law scholarship is experiencing a revival of interest in the normative. Indeed, a variety of scholarly works, otherwise unrelated by school or approach, have recently urged a new look at the concept of evaluation or judgment in the law of criminal defenses. 9 That Wilson has now added his name to this growing list of scholars raises questions about the "new normativity" in criminal law: what it means, why it is currently of interest in the academy, and whether it will last.

This review considers these questions in the context Wilson has chosen for himself-a serious examination of the phenomenon known as the abuse excuse. Part I examines the difficulties of the project Wilson has chosen-a theoretically ambitious work wrapped in a plot-thickening spate of criminal law horror stories. Part II considers whether we can safely identify abuse excuses by focusing, as Wilson does, on syndromes, causal explanations, and self-control. Part III explores Wilson's hope that judgment rescues us from the abuse excuse by considering three different models: judgment as community, judgment as character, and judgment as critique.

In the end, Wilson's "judgment" disappoints. Wilson wants to blame the abuse excuse on a conceptual flaw in modern defenses. But, if taken seriously, Wilson's argument extends much further, indicting a theory of excuse that now governs understandings of both traditional and modern defenses. And, if that is true, the abuse excuse turns out to be a rather empty idea-the abuse is everywhere the failed theory is and, in this sense, nowhere in particular. Wilson is unable to see this because he is convinced that modernity is to blame. He wants very badly, for example, to indict modern "social movements" 10 for their role in creating excuses he considers abusive, such as battered women's syndrome. Wilson's blistering critique of battered

9. For the most comprehensive work to date on this issue, see Dan M. Kahan \& Martha C. Nussbaum, Two Conceptions of Emotion in Criminal Law, 96 COLUM. L. REV. 269 (1996); see also Jody D. Armour, Race Ipsa Loquitur: Of Reasonable Racists, Intelligent Bayesians, and Involuntary Negrophobes, 46 STAN. L. REV. 781, 787-90 (1994) (arguing that the reasonable man incorporates normative judgments); Kyron Huigens, Virtue and Inculpation, 108 HARV. L. REV. 1423, 1456-72 (1995) (asserting a theory of inculpation dependent upon judging defendants' motives and practical reasoning); Cynthia Kwei Yung Lee, Race and Self-Defense: Toward a Normative Conception of Reasonableness, 81 MINN. L. REV. 367, 495-99 (1996) (recounting reasons supporting a normative conception of reasonableness in self-defense cases); Victoria Nourse, Passion's Progress: Modern Law Reform and the Provocation Defense, 106 YALE L.J. 1331, 1368-83 (1997) (rejecting the current model of self-control and arguing that it allows the law to incorporate controversial judgments about men, women, and their relationships).

10. P. 101 (arguing that "social movements" appear to have "compelled" courts to cognize battered women's claims); see also DERSHOWITZ, supra note 2, at 3-6 (attributing the rise of the abuse excuse to the proliferation of syndromes, "politically correct" social movements, junk science, and a "general abdication of responsibility by individuals, families[, and] groups"). 
women's claims, ${ }^{11}$ however, leaves out an important parallel: What of men who claim that they were provoked to kill their wives? Wilson does not appear to be disturbed by such claims, embracing provocation as a "traditional" defense despite its obvious potential for abuse. ${ }^{12}$ If Wilson is to take judgment seriously, he cannot indict some defenses for failing to judge-demanding that battered women, for example, show more self-control-but not others-partially excusing provoked men precisely when they do lose selfcontrol. Indeed, this selectivity risks leaving the impression that Wilson's "judgment" is simply a conceptual peg upon which to hang political predilections. This is unfortunate, for the revival of interest in evaluative approaches may be of enormous importance to criminal law theory: The new normativity deserves more than a vague dismissal as politics wrapped in judgmental garb.

\section{WHEN THEORY MIXES WITH DRAMA}

Accounts of the abuse excuse follow a familiar pattern. Case studies form the bulk of the popular literature, treating us to tales of defendants claiming excuses because of their genes, their diets, and even their mothers. Featured prominently are the rare or celebrated cases: battered women who kill sleeping husbands, ${ }^{13}$ Dan White's "Twinkie defense," 14 and the Menendez brothers' claims of child abuse. ${ }^{15}$ Professor Wilson's account is no different. Like a well-plotted novel, the characters and their tragedies move through the material, leaving us breathless for the next account of the law gone wrong.

Each of the book's five chapters addresses a serious theme such as expert testimony, self-control, and changing notions of responsibility. Each of these themes are, in turn, illustrated by a series of cases. In contrast to his tempered discussions of conceptual issues, Wilson is blunt about the cases. Consider his discussion of the "baby blues" defense, ${ }^{16}$ Wilson's term for postpartum depression:

Kathleen Householder was depressed after the birth of her daughter. Frustrated at the noise the infant was making, she hit her with a rock, put her in a plastic bag, and threw her into the river. She told the police her infant had been kidnapped and went on television to urge her return. In time she confessed to the

11. See pp. 48-58.

12. P. 103; see text accompanying notes 89-106.

13. See FLETCHER, supra note 2, at 133-35 (describing the case of Judy Norman); see also DERSHOWITZ, supra note 2, at 45 (suggesting that battered women's claims frequently arise in cases where the victim "is asleep").

14. See FLETCHER, supra note 2, at 28-33.

15. See DERSHOWITZ, supra note 2, at 21-24; FLETCHER, supra note 2, at 141-47.

16. P. 33. 
killing. Astonishingly, the prosecution accepted a plea of voluntary manslaughter, and Householder spent twenty-two months in jail. ${ }^{17}$

The intended message of this story is obvious: Our criminal justice system has lost its bearings. As Wilson's book progresses, this message intensifies. What is the average reader to think when she reads that rioters like Damian Williams and Henry Watson claimed "mob frenzy" to excuse their nationally televised bludgeoning of Reginald Denny? ${ }^{18}$ Skepticism is likely to yield to horror when the reader learns, from Wilson, that some women claiming battered women's self-defense "arranged and paid for their husband's [sic] execution."19 Add on all the highly publicized cases, then invoke names ${ }^{20}$ like "battered person syndrome"21 and "premenstrual stress" defense, ${ }^{22}$ and the situation seems self-evidently grave.

All of this poses a serious challenge to Wilson's greater intellectual aims. For many readers, I suspect, the cases overwhelm Wilson's argument, obscuring his theoretical distinctions between hard and soft science, good and bad evidentiary rules, or explanation and judgment. On one level, Wilson recognizes this danger. At the opening of the book, he remarks that the true complexities of criminal behavior are lost when a particular "trial . . . has caught the public's attention." ${ }^{23}$ On another level, Wilson seems caught up in the very sensationalism he rejects. Like others before him, Wilson cannot resist the lure of the popular trial gone wrong. He freely interweaves references to Dan White, Bernhard Goetz, and the Menendez brothers throughout his analysis, supporting his argument by anecdote while urging repeatedly the need for more rigorous intellectual analysis.

If Wilson's case histories tend to overwhelm his theoretical concerns, they also unbalance his attempts to appear evenhanded. Wilson intends a dispassionate account of the abuse excuse, but the relish with which he de-

17. P. 34.

18. As Wilson explains it, "[T]he defense argued that persons caught up in a mob frenzy could not have formed the specific intent necessary to sustain a conviction for attempted murder or aggravated mayhem." P. 27.

19. P. 65.

20. Part of the shock value of the abuse excuse comes from a bit of word play. As every criminal law scholar knows, there is no such thing as the "XYY chromosome defense" or the "premenstrual syndrome defense" in traditional or even modern common law. The rhetorical strategy here is to diminish the importance of the defense by describing it in the most specific and reductionist of terms. It is a familiar strategy. See, e.g., Laurence H. Tribe \& Michael C. Dorf, Levels of Generality in the Definition of Rights, 57 U. CHI. L. REV. 1057, 1065-67 (1990) (arguing that the Supreme Court has used such a strategy to reject claims of "fundamental" rights, by describing a right in extremely specific terms and thereby "disconnect[ing] it from previously established rights").

21. P. 67; see p. 97.

22. P. 23; see pp. 34-36.

23. P. 5 . 
scribes difficult cases tends to keep the stories center stage. At the beginning of the book, Wilson tries hard to temper the claims of other abuse excuse enthusiasts. He rejects, as "greatly exaggerated," 24 Professor Dershowitz's expansive list of oddball excuses. He reminds readers that claims of black rage and steroid-induced frenzy are rare and rejects the XYY chromosome excuse and the "pornography-made-me-do-it" defense as miserable failures. $^{25}$ Indeed, Wilson asserts confidently that "there is no avalanche of 'abuse excuses' afflicting American criminal law."26

If this true, why does Wilson spend so much time ridiculing the Menendez brothers' claims of child abuse or Dan White's diminished capacity defense? ${ }^{27} \mathrm{He}$ tells us that these cases are important in his fight for a criminal law based on judgment rather than explanation. But will anyone actually remember the importance of judgment by the time they have read of women throwing babies away, hiring killers to shoot their husbands, or claiming premenstrual stress ("PMS") drove them to murder? ${ }^{28}$ I suspect that many readers will simply pick and choose the stories that best fit their rough, preconceived ideas of the problems facing our criminal justice system. Some readers will find confirmation of an excuse epidemic, while others will conclude that Wilson is simply picking on the usual suspects-the alcoholics, the battered, the downtrodden, and the poor. If asked, Wilson would likely reject both positions, arguing that America's crime policies are "more complex" 29 than most persons imagine. In the end, however, one wonders whether Wilson's more temperate intellectual sentiments are strong enough to be heard above the noisy drama of the cases he describes.

Perhaps this is the price that a writer must pay if he seeks both to make strong theoretical claims and speak to a popular audience. Whatever the cause, the result is the same: Moral Judgment is a book with two distinct voices. One is the voice, steady and temperate, of a distinguished scholar seeking answers to complex problems of theory and fact. The other is the voice of the raconteur, the storyteller, who preaches not by analysis but by

24. P. 23. The list Wilson suggests is exaggerated includes "drug or alcohol addiction, battered woman syndrome, black rage defense, XYY chromosome defense, mob mentality defense, pornography defense, post-traumatic stress disorder, premenstrual stress syndrome, rape trauma syndrome, steroid defense, and urban survivor syndrome." P. 23; cf. DERSHOWITZ, supra note 2, at 321-41 (providing a "Glossary of Excuses").

25. See p. 24.

26. P. 89.

27. See pp. 22-26, 44-48.

28. See p. 34 (describing how the defendant "threw [the baby] into the river"); p. 65 (describing how each defendant "arranged and paid for [her] husband's execution"); p. 34 (describing how the defendant "rammed her boyfriend against a utility pole").

29. P. 5; see also pp. 4-5 (discussing the "complexities" of the question of whether America punishes too little or too much). 
example. This effect was certainly not Wilson's intent. Indeed, at the end of the book, he launches a brief and seemingly unrelated attack against "storytelling" as legal analysis. ${ }^{30}$ It is hard to read this book as a whole, however, without coming to the conclusion that Professor Wilson has written a story of his own. That story, I contend below, suggests more about Wilson's concept of judgment than do Wilson's theoretical pronouncements on the matter. Kant once said that "examples are the go-cart of judgment" 31 - a sentiment that Wilson's work, albeit inadvertently, demonstrates quite clearly.

\section{ABUSIVE EXCUSES: EXPERTS, SOCIAL SCIENCE, AND SELF-CONTROL}

Accounts of the abuse excuse raise the persistent dilemma of identification: How do we know it when we see it? Neither Professor Dershowitz, who originated the discussion, nor Professor Wilson, who has continued it, want to eradicate all excuses. ${ }^{32}$ That, in turn, raises the obvious question of which defenses should count as abusive. Attempting to answer this question, Wilson offers a variety of theoretical distinctions. He suggests, for example, that abuse excuses rely too heavily on syndrome evidence; ${ }^{33}$ that they ask juries to embrace dubious generalizations rather than hard facts; ${ }^{34}$ and that they depend upon sympathy for the disadvantaged who claim to lack selfcontrol. ${ }^{35}$ In what follows, I consider each of these arguments and, finding none satisfactory, I return to Wilson's examples to consider whether these provide clues to the real abuse excuse.

\section{A. Experts, Facts, and Generalizations}

Wilson begins his analysis by focusing on "faulty experts." 36 Wilson's concern here is with a particular brand of expert testimony. Although a social scientist himself, Wilson argues that lawyers in criminal trials place far too much reliance on "social science" evidence. According to Wilson, fingerprint, DNA, or ballistic analyses are "hard science" 37 and thus are capable

30. See pp. 109-10.

31. ImManuel Kant, Critique Of PURe Reason B173 (N.K. Smith trans., St. Martin's Press 1963).

32. See DERSHOWITZ, supra note 2, at 318 (noting that excuses, even those based on a history of abuse, may be a relevant factor in the calculation of responsibility and punishment); pp. 102-03 (noting with approval defenses such as self-defense, necessity, and provocation).

33. See pp. 20-21, 51-58.

34. See pp. 14-17.

35. See pp. 43,85 .

36. P. 1.

37. See pp. 14-15. 
of helping us decide whether a defendant "acted rightly or wrongly." 38 By contrast, social science evidence purports to explain why a defendant "was at the scene and what was running through his mind at the time." 39 Predictions about the statistical likelihood of such factors may be good social science, Wilson argues, but they are "useless legal advice . . . except in the very unusual case when the odds are so high as to approach the confidence we have in a fingerprint." 40 We would all be better off, Wilson concludes, if judges would "ban[] psychiatric and social-science experts altogether."41

Wilson presents vivid examples of bad expert testimony. The reader learns of the expert who testified in the Rodney King trial that a frame-byframe analysis of King's movements showed in every frame that King was "hostile or aggressive." 42 Then there is the psychiatrist who testified at a death penalty hearing "that there was a 'one hundred percent and absolute' chance that the defendant would kill again." 43 Wilson reserves extended treatment, however, for the expert testimony typically associated with battered women's syndrome. ${ }^{44}$ Indeed, Wilson is positively agog that such testimony, which he describes as "scientifically suspect, philosophically debatable, and legally unnecessary" 45 has been accepted by so many lawyers and judges.

Wilson is neither the first person to question the role of so-called "junk science" in the courtroom, ${ }^{46}$ nor the first to challenge the conclusion that "learned helplessness" describes all battered women. ${ }^{47}$ The question remains, however, whether his argument against expert testimony can really

38. P. 14.

39. P. 14.

40. Pp. 14-15.

41. P. 20.

42. P. 15.

43. P. 19 (quoting Paul C. Giannelli, "Junk Science": The Criminal Cases, 84 J. CRIM. L. \& CRIMINOLOGY 105, 113-14 (1993)).

44. See, e.g., pp. 48-58, 62-69.

45. P. 56.

46. See, e.g., FLETCHER, supra note 2, at 28-33; id. at 47 ("'P]sychiatrists should not be able to shape the jury's judgment with imperial claims of expertise."). See generally PETER W. HUBER, GALILEO'S REVENGE: JUNK SCIENCE IN THE COURTROOM (1991) (discussing the negative impact that certain forms of science have had on the American legal system).

47. See, e.g., David L. Faigman, Note, The Battered Woman Syndrome and Self-Defense: A Legal and Empirical Dissent, 72 VA. L. REV. 619, 636-43 (1986) (criticizing the concepts of "cycle theory" and "learned helplessness" as empirically and theoretically unsound). Nor are such critiques limited to so-called "conservative" positions. See, e.g., Linda L. Ammons, Mules, Madonnas, Babies, Bathwater, Racial Imagery and Stereotypes: The African-American Woman and the Battered Woman Syndrome, 1995 WIS. L. REV. 1003, 1070-72 (arguing that the learned helplessness theory may be at odds with stereotypes about African American women and, therefore, may prove unhelpful as a legal strategy in some self-defense cases). 
stand up to close scrutiny. Although Wilson wants psychiatrists and social scientists banished from the courtroom, he does not argue that we should eliminate expert testimony altogether. ${ }^{48} \mathrm{He}$ approves of the use of expert testimony in a variety of cases involving DNA evidence, fingerprinting, and other matters. ${ }^{49}$ Where then is the dividing line between the "good" and the "bad" science? If syndrome-science is what we need to banish, how are we to recognize it?

Enter Wilson's distinction between generalizations about group characteristics and facts. Wilson complains that social science testimony has led juries to consider generalizations about group behavior rather than to consider the facts of individual cases..$^{50}$ Speaking of battered women's syndrome, for example, Wilson questions how the syndrome can possibly "predict how this woman felt in these circumstances?"51 Later, Wilson amplifies this in his discussion of People v. Humphrey, ${ }^{52}$ arguing that the Supreme Court of California erred when it reversed for failure to admit evidence of battered women's syndrome because there was no need for the evidence. According to Wilson, there was no issue "'beyond the ken' of a jury";53 rather, "[e]very fact relevant to convicting or acquitting her was already known to [it]." 54

The distinction between group generalizations and facts sounds plausible at first but tends to dissolve in practice. Indeed, one need not consider fairly rare claims, like the battered women's cases, ${ }^{55}$ or even cases that involve expert testimony, to see that group generalizations are unavoidable in the criminal law. How else can we discern the intent of a defendant without judging his actions against those of similarly situated persons? When juries generalize that men naturally lose control when their wives cheat ${ }^{56}$ or that black youth are likely to be violent aggressors, ${ }^{57}$ they are making group generalizations as clearly as they would in cases in which experts testified. In-

48. See pp. 13-14.

49. See pp. 13-14.

50. See pp. 13-16.

51. P. 16.

52. 921 P.2d 1 (Cal. 1996).

53. P. 56.

54. P. 55.

55. Wilson acknowledges that these cases are indeed rare. See p. 3 (restating, with apparent approval, claims that "the battered-woman syndrome has been introduced into many trials of women who killed their husbands, but such killings are unusual").

56. See H.L.A. HART, PUNISHMENT AND RESPONSIBILITY: ESSAYS IN THE PHILOSOPHY OF LAW 33 (1968) (noting the "common-sense" generalization that men are not capable of self-control "when confronted with a wife in adultery").

57. See Armour, supra note 9, at 787-90 (noting the pervasive belief in America that "blacks tend to be 'violence-prone"'). 
deed, any time the law imposes a reasonable person standard, it requires that juries make assumptions about human behavior-assumptions that put the defendant in a group of analogously situated persons.

My point is not to doubt Wilson's claim that there is bad social science evidence being introduced at trial. Indeed, I suspect that it is just as easy to find examples of junk social science as of junk science. My point is that barring a vast flood of experts will not eliminate generalizations-it will simply keep juries focused on generalizations that they already believe to be true. Those generalizations, however, are apparently fine with Wilson. This raises an obvious question: Why is Wilson so sure that the jurors' existing generalizations are always sounder than the generalizations of experts? Just as no expert can be one-hundred percent sure that a convicted killer will kill again, juries cannot be one-hundred percent sure about human behavior. And, if that is true, then Wilson's complaint cannot be about group generalizations per se. What he must be complaining about are "bad" generalizations and "junk" social science. This brings us back to where we started, however, looking for ways to distinguish "good" from "bad" science.

Ultimately, Wilson suggests that all we must do is ask whether the jury needs such expert testimony. ${ }^{58}$ Rule 702 of the Federal Rules of Evidence provides that expert testimony should be admitted only when the evidence will help the jury assess the issues in the case. ${ }^{59}$ But necessity is not as simple an evidentiary question as Wilson suggests. ${ }^{60}$ There are two separate issues here: One is about the nature of expert opinions-what kind of testimony the jury should hear-and the other is about relevance-what legal theory makes this testimony relevant. Experts are the opinionated messengers of theories of relevance provided by the substantive criminal law. The form of their testimony may exacerbate the situation, but focusing exclusively on form obscures the central question of relevance. There would be no dispute about expert testimony in the Menendez case if the judge had

58. See pp. 10-21; see also pp. 51-52, 54-56 (arguing that evidence of battered women's syndrome was not needed to decide the cases described).

59. See FED. R. EVID. 702 ("If scientific, technical, or other specialized knowledge will assist the trier of fact to understand the evidence or to determine a fact in issue, a witness qualified as an expert... may testify thereto.").

60. Wilson's argument that there is no good scientific evidence for battered women's syndrome does not exhaust the issue of appropriate testimony in battered women's cases. Even those who believe that battered women's syndrome is essentially a political reevaluation of the law of self-defense have acknowledged that evidence of battering may be introduced to bolster the defendant's credibility and that this use of expert testimony follows well-established evidentiary principles. See, e.g., Robert P. Mosteller, Syndromes and Politics in Criminal Trials and Evidence Law, 46 DUKE L.J. 461, 479 (1996) ("When BWS [battered women's syndrome] is used for the purpose of restoring the credibility of the defendant by countering prosecutorial impeachment, no specialized evidence showing BWS to be a 'syndrome' is required."). 
ruled that the evidence was irrelevant, a ruling that requires a particular legal theory of self-defense. In short, Wilson's argument about experts skirts the fundamental issue: When should the law excuse and when should it punish?61

\section{B. Self-Control, Sometimes}

Wilson himself appears to recognize that we cannot safely identify the "bad" excuses simply by looking to whether they are supported by syndrome evidence. Indeed, he soon becomes critical of excuses, like the intoxication defense, that are not typically associated with social science testimony. ${ }^{62}$ As Wilson presses on, he moves from syndromes to self-control, focusing on questions of personal responsibility. ${ }^{63} \mathrm{He}$ writes: "We are all exposed to temptation, we all on occasion lack self-control," but the law should "raise, not lower, the ante in these circumstances"; 64 it should encourage individual responsibility. In the second chapter, entitled Self-Control, Wilson analyzes this topic at length. ${ }^{65}$

We know at a glance that we have moved from the realm of oddball excuses and strange syndromes: Wilson's first target here is the intoxication defense, a well-established excuse that has typically been left out of the "abuse excuse" canon. Reversing traditional legal understandings, Wilson argues that getting drunk should increase, not decrease, culpability. According to Wilson, cases like People v. Guillett, ${ }^{66}$ in which the Michigan Supreme Court held intoxication to be a defense to an attempted rape, ${ }^{67}$ simply have it backwards. Intoxication reveals "a willful lack of self-control" that should "lead us to judge the person as . . fully culpable." 68 From this perspective, the abuse excuse results not from the use of faulty experts or group

61. See Schulhofer, supra note 3, at 838-40 (questioning proposals by Professor Fletcher that focus on expert testimony when the real problem lies in the "substantive standard" of liability determining relevance).

62. See pp. 28-33.

63. See p. 27.

64. P. 27. Wilson later elaborates on this point, maintaining that the law should "foster selfcontrol by stigmatizing and punishing its absence," because excusing such lapses will simply encourage "the frequency" of failed efforts at self-control and leave the law lurching toward the embrace of a "vast list of criminal causes that, if adopted, will erase the distinction between law and science." P. 43.

65. See pp. 22-43.

66. 69 N.W.2d 140 (Mich. 1955).

67. See pp. 28-29. Quite rightly, I think, Wilson asks some tough questions of this case and the porous line between specific and general intent: "Is a man trying to have sex with a woman ever so drunk as to be unaware that he is trying to have sex with her? And if he is aware of it, how can he be said to lack the intent to have sex?" P. 30.

68. P. 31. 
generalizations but from the failure to demand that people simply control themselves.

Fortified by this analysis, Wilson extends the theme of self-control to other defenses, including claims based on postpartum depression, premenstrual syndrome, and some versions of the insanity defense. ${ }^{69} \mathrm{He}$ decries modern legal developments that have sought to reduce punishment in cases in which the defendants "seem to lack self-control." 70 According to Wilson, defendants should be held "responsible for their actions"71 in all but the rarest of cases. Wilson sums it all up in a "commonsense" injunction to "get tough": "There are, in fact, things that [a] woman can do to control the effects of extreme PMS . . . just as there are things men can do to avoid the effects of steroids or alcohol. The law ought to encourage us, rather sternly, to do these things." 72

All of this will sound plausible, no doubt, to many lay readers. For those who know something about criminal law defenses and theories of selfcontrol, however, Wilson's claims quickly unravel. For several decades, scholars have argued that most of our excuses-and some of our justifications-are based on defendants' inability to freely choose a course of action. Duress, self-defense, provocation, and insanity are widely understood as defenses that exculpate because the defendant's practical ability to choose, and thus to exercise self-control, has been impaired. ${ }^{73}$ If this is right, how is it possible to draw the line between the abusive excuses where we should en-

69. See pp. 33-43. As Wilson acknowledges, however, the story of these defenses is quite mixed. After discussing successful PMS defenses in Britain, Wilson notes that American judges have commendably "resist[ed] this line of argument." P. 35. Similarly, with respect to insanity, Wilson first discusses a rule that would excuse a defendant's actions as "the product of a mental disease or mental defect"- the Durham rule-only to acknowledge that this rule "was rejected by the courts." $P$. 37 (citing Durham v. United States, 214 F.2d 862, 874-75 (D.C. Cir. 1954), which formulated what has become known as the Durham rule). In both examples, however, the outmoded or irrelevant formulations of these defenses are intended to support Wilson's argument that the law has encouraged a lack of self-control.

70. P. 43.

71. P. 37.

72. P. 36.

73. See Herbert L. PACKer, The Limits of the Criminal SANCtion 112 (1968) ("The reasons for recognizing excuses . . . have to do with preserving human autonomy and with maximizing the opportunity to exercise choice."); see also HART, supra note 56, at 33, 46-53 (emphasizing a theory of excuse dependent upon respecting the individual as a "choosing being"). For illustrations of how various defenses relate to a lack of self-control, see Kahan \& Nussbaum, supra note 9, at 305-06 (arguing that the "most popular account" of the common law formulation of provocation is based on impairment of choice, volition, and self-control); id. at 328 (stating that the "classic account" of selfdefense assumes that "a person has no realistic choice but to use deadly force"); id. at 334 (recounting a "popular" account of duress as "exculpating because it impairs 'a person's capacity to choose"'); and id. at 341-42 (urging that the "irresistible impulse" or "volitional impairment" forms of the insanity defense excuse the defendant "when a mental disease impairs her capacity to control her behavior"). 
courage self-control and the nonabusive excuses where loss of self-control is permissible? If one takes Wilson's theory to its logical conclusion-that we need to increase defendants' self-control - then why not demand that those who act under duress or provocation also exercise self-control? If most defenses seek to excuse based on defendants' lack of self-control, then Wilson's theory has the potential to wipe the slate clean - to bar almost every excusing feature of the criminal law. Explained another way: If the point is to encourage self-control, and the law excuses defendants' lack of selfcontrol, then almost all excuses become abuse excuses.

Wilson, of course, does not want to go quite this far. He tells us he would preserve a small number of excuses, repeatedly emphasizing the limited number and range of these defenses. He urges that people should "be held responsible for all but a relatively small number of actions that are truly involuntary or the product of manifest duress." 74 If people "break the law and cannot reasonably claim one of a small number of defenses, then they ought to be held accountable." 75 Exceptions should be made only "for a few compelled actions or wholly involuntary reflexes." 76 Indeed, Wilson repeatedly cautions that "once we leave the narrow excuses of duress or insanity, we will have, in the main, a vast list of criminal causes that, if adopted, will erase the distinction between law and science." 77

The difficulty with this argument is that we have no idea why the "small number" of "narrow" excuses differ from the rest. Although Wilson urges that we eradicate some defenses, like intoxication, to increase self-control, he approves of other defenses precisely because the defendant has lost selfcontrol. He embraces claims based on a reasonable lack of self-control grounded in provocation or duress. ${ }^{78}$ How can Wilson demand that defendants exercise self-control when they are drunk but not when they are provoked or threatened? If we are to encourage self-control, why not treat the defendant provoked by anger like the one driven by fear and tell both that there is "something that they can do"? If the battered woman must control herself, why should the cuckolded man be permitted to let his emotions run free?

Lest these questions suggest a rather obvious inconsistency, let me make clear that I have posed a rather commonplace dilemma known to many criminal law scholars. It is well-accepted within the criminal law academy that if one takes the self-control argument to its logical conclusion, the theory

74. P. 40 (emphasis added).

75. P. 41 (emphasis added).

76. P. 41 (emphasis added).

77. P. 43 (emphasis added).

78. See pp. 103, 42-43. 
"has no limit." Once we accept some reasons for a lack of self-control, why not accept all reasons? If self-control is the touchstone of excuse, then any reason should do. Quickly we slide from claims that a defendant killed because a gun was pointed at his head to claims that a defendant killed because someone parked in his parking space. ${ }^{80}$

To avoid hitting this problem head-on, Wilson segues, asking the reader to focus on the difference between a causal theory of excuse and one based on responsibility. Uniting themes of self-control and expert testimony, Wilson argues that the real problem is that jurors are being asked to speculate about the causes of defendants' behavior rather than to assess individual responsibility. ${ }^{81}$ Here, Wilson aims at an important distinction between explanation and evaluation, a distinction that is crucial to the "new normativity's" approach to criminal law defenses. More will be said on this later ${ }^{82}$ but it is important to note that this distinction falls short in solving the riddle of self-control.

First, let us look at the idea of causation. Wilson wants to juxtapose "cause" as a behavioral, nonnormative, notion against "responsibility" as a normative or judging process. But he is unwilling to acknowledge that judgments of causation may be both factual and normative. When jurors accept the argument that the defendant was provoked to kill upon learning that his wife had cheated, one might say that they are looking for a cause for the seemingly inexplicable. But isn't it equally plausible that their judgments of factual cause - why the defendant acted as he did - are infused with normative judgments about responsibility? How do we know whether the jury is saying that the victim's infidelity factually caused her husband's breakdown or whether it is making a normative judgment that unfaithful women deserve punishment or heartbroken men deserve compassion? If cause is to stand in for behavioristic or mechanistic explanation, then Wilson must make this distinction far more clearly.

Wilson hopes to avoid this problem by relying on the work of the distinguished criminal law scholar Michael Moore, who has rejected so-called "causal theories" of criminal law defenses. ${ }^{83}$ Moore is surely right to reject

79. Huigens, supra note 9, at 1440 (rejecting the "determininst's defense" that everything is caused and, therefore, we have no choice); see also Michael S. Moore, Causation and the Excuses, 73 CAL. L. REV. 1091, 1112-13 (1985) (noting that the theory at its extreme dictates that no actions would be punishable).

80. See State v. Raguseo, 622 A.2d 519, 522-23, 525-26 (Conn. 1993) (describing how the defendant killed a man who had parked in his parking space and the jury was instructed that it could return a manslaughter verdict based on the defendant's extreme emotional disturbance having been brought on by his having his parking space taken).

81. See pp. 38-43.

82. See text accompanying notes 128-202 infra.

83. See, e.g., pp. 17-18, 40, 43. 
such theories, but that does not answer the question I have posed for Wilson: Even assuming a causal theory is wrong, how do we know when we should or should not demand self-control? Moore's response is that excuses depend upon defendants' capacity for practical reasoning rather than self-control. ${ }^{84}$ That answer may prove better than causal explanations, but it does not clearly resolve the problem. If, as Moore would have it, we excuse in the case of compulsion because compulsion interferes with "practical reasoning," 85 we are still left asking when defendants are "compelled" in this sense. ${ }^{86}$ Why is it, for example, that law and society frequently see men who kill their cheating spouses as at least partially incapable of reason and "compelled" to act, whereas they are quick to question whether women who kill their battering husbands in fear are similarly "compelled"?

\section{Will the Real Abuse Excuse Please Stand?}

As Wilson's distinctions begin to unravel, the cases he reports reemerge as the most important and telling part of his work. In the third chapter of his book, entitled Self-Defense, Wilson expands his earlier critiques of expert testimony and self-control, this time in the context of self-defense doctrine. ${ }^{87}$ What emerges is a pragmatic division between abusive and nonabusive excuses. On the nonabusive side of the scale are the small range of "traditional" excuses such as self-defense, provocation, and duress; on the abusive side are intoxication, imperfect self-defense, and diminished capacity. ${ }^{88}$

The pragmatic line drawn here raises interesting questions about the consistency of Wilson's claims. This point can be illustrated by an examination of Wilson's account of a "traditional" excuse: the provocation defense. ${ }^{89}$ Wilson asserts that the provocation defense is appropriate to mitigate punishment when a "killing was the result of . . . behavior that would make a reasonable person immediately lose self-control." 90 Technically, this is not

84. See Moore, supra note 79, at 1129-32.

85. Id. at 1129.

86. See, e.g., Huigens, supra note 9, at 1442 (arguing that Moore's theory does "not develop" the focus on practical judgment that might resolve the problem of determinist theories).

87. See pp. 44-69. These themes are repeated and amplified in the concluding chapters of the book. Chapter Four offers a brief history of the development of excuses. See pp. 70-88. Chapter Five concludes the book by summarizing the arguments Wilson has made in the first four chapters, tying them to contemporary social movements. See pp. 89-112.

88. For Wilson's approval of particular defenses, see pp. 40, 43 (duress); pp. 48, 103 ("traditional" or "well-recognized" self-defense); and p. 103 (provocation). For his disapproval, see pp. 2427 (diminished capacity); pp. 30-33 (intoxication); and pp. 59-62 (imperfect self-defense).

89. I use the term provocation "defense" in its generic sense. Provocation claims do not lead to acquittal; typically, they mitigate the offense from murder to manslaughter.

90. P. 103. 
an accurate description of the doctrine: The traditional provocation defense requires a showing that the provoking act was normatively wrong. ${ }^{91}$ Indeed, in a small number of states today, provocation is confined to specific categories of wrongs, such as adultery, mutual combat, or false arrest. ${ }^{92}$ Wilson's version, however, reflects a standard hornbook paraphrase of a more modern provocation defense. ${ }^{93}$

Because provocation has a long history as a defense and is not commonly labeled as an abuse excuse, it may seem safe from misuse. In fact, provocation cases can quite easily appear to defy common sense. If Wilson is concerned about the "baby blues" defense, ${ }^{94}$ what about the "rejection blues" defense? Consider the following claims grounded in both modern and traditional versions of the provocation defense. When Carlos Guevara learned that his wife was seeking divorce, they argued, he left the room to get a two-foot board, beat and strangled her to death, found the divorce papers, and then fled to his girlfriend's apartment. ${ }^{95}$ The jury was instructed that it could return a manslaughter verdict because the defendant was emotionally upset — presumably by the divorce—at the time of the killing. ${ }^{96}$ Similarly, when Kenneth Peacock found his wife in bed with another man, he got his shotgun and scared his rival off; several hours and a gallon of wine later, Peacock shot and killed his wife. ${ }^{97}$ To the judge assigned to this case, there

91. See Nourse, supra note 9, at 1340-41. Indeed, as Jeremy Horder's work shows, the historical record is inconsistent with the claim that the modern ideal of self-control shaped the defense in its early common law forms. See generally JEREMY HORDER, PROVOCATION AND RESPONSIBILITY (1992). Certainly, it cannot explain why the truly traditional form of the provocation defense is limited to particular kinds of triggering events (e.g., adultery, mutual combat, or false arrest), rather than encompassing all reasons that might prompt an individual to lose control.

92. See SANFORD H. Kadish \& STEPHEN J. SchUlhofer, CRIMINAL LAW AND ITS PROCESSES: CASES AND MATERIALS 442 (5th ed. 1989) (listing cases that construed provocation only in the most limited manifestations). As this text notes, under the traditional common law view, "Only certain narrowly defined provoking circumstances . . could justify a manslaughter verdict." Id. at 441-42.

93. See WAYNE R. LAFAVE \& AUSTIN W. SCOTT, JR., CRIMINAL LAW § 7.10(b), at 654-57 (2d ed. 1986) ("What is really meant by 'reasonable provocation' is provocation which causes a reasonable man to lose his normal self-control.").

94. P. 33.

95. See People v. Guevara, 521 N.Y.S.2d 292, 293 (App. Div. 1987).

96. See id. at 293-94. Although the jury was given manslaughter instructions based on provocation, it found Guevara guilty of second-degree murder. That the law would permit a manslaughter verdict in such a case, however, should be controversial. To put it colloquially: $\mathrm{He}$ is cheating on her, $h e$ beats her up to stop the divorce, and he is claiming that he was provoked? And, indeed, the appellate court's conclusion that the defense was not "reasonable," id. at 294, suggests that no manslaughter instruction should have been given; $c f$. $i d$. ("The court's charge on extreme emotional disturbance was proper....").

97. See Karl Vick, Md. Judge Taking Heat in Cuckolded Killer Case, WASH. POST, Oct. 30, 1994, at A1. 
was no question that Peacock suffered an adequate provocation resulting in "uncontrollable" rage: He sentenced Peacock to eighteen months to be served on work release, based on a plea of voluntary manslaughter. ${ }^{98}$ When Randall Dixon saw his fiancée dancing with another man, he knocked her down on the dance floor. ${ }^{99}$ Later that evening, he beat her and, when she lost consciousness, he resuscitated her, only to beat her again. The jury returned a verdict of manslaughter, and the appellate court affirmed, finding that the jury, by law, was entitled to conclude that Dixon was either reckless or that he was suffering from emotional distress, presumably provoked by the fact that his fiancee had danced with another man. ${ }^{100}$

I suspect that Wilson, like many, would find these cases disturbing. ${ }^{101}$ But, if so, none of Wilson's theoretical claims account for it. Consider Wilson's argument that abusive excuses rely upon dubious syndromes. ${ }^{102}$ There is no "male rejection syndrome" associated with the provocation cases I listed above. Men do not have to call expert witnesses to explain that a reasonable person would lose self-control when his wife cheats or leaves; the reasonableness of such arguments is assumed. ${ }^{103}$ Or consider Wilson's claim that too many excuses invite jurors to consider group generalizations rather than the facts of a particular case. ${ }^{104}$ Provocation is not overtly styled as a defense about any particular group even though it surely does require ju-

98. See Ann G. Sjoerdsma, Justice: 18 Months for a Wife's Life, CHI. TRIB., Nov. 14, 1994, at 21 ("Within two weeks of sentencing, the man is back on the road driving his rig."); see also Lynn Hecht Schafran, There's No Accounting for Judges, 58 ALB. L. REV. 1063, 1063-64 (1995) (discussing Judge Cahill's sentence in the Peacock case).

99. See Dixon v. State, 597 S.W.2d 77, 78 (Ark. 1980).

100. See id. at 79-80. The defendant was convicted of manslaughter and argued that the evidence was insufficient to support the verdict. The court found the evidence sufficient either under a theory of recklessness or extreme emotional distress, i.e., provocation. See id. at 20 ("We think the evidence was more than sufficient to support a conviction for manslaughter under either $\S 41$ 1504(1)(a) [extreme emotional disturbance] or § 41-1504(1)(c) [recklessness].").

101. One might argue that provocation cases are not abuse excuses because the defendant does not claim a past history of abuse or battering. But most accounts of the abuse excuse include-as Professor Dershowitz so graphically put it-"sob stories." DERSHOWITZ, supra note 2, at 43. Certainly, the idea that one killed because one was rejected should qualify, in abuse excuse terminology, as a "sob story."

102. See pp. $46-47$ (criticizing battered child syndrome); pp. 48-58 (criticizing battered women's syndrome); pp. 66-67 (criticizing battered person syndrome).

103. This is not to say that male defendants do not bolster their provocation claims with psychiatric testimony; they frequently do. But often the defendant claims compassion based not on scientific or even social scientific propositions, but rather on "“common-sense' generalizations about human nature." HART, supra note 56, at 33. As Hart noted a generation ago, such generalizations allow the conclusion that men are "capable of self-control when confronted with an open till but not when confronted with a wife in adultery." Id.

104. See pp. 14-15. 
rors to make assumptions about that group we call reasonable males. ${ }^{105}$ Finally, if Wilson is worried that defenses like intoxication do not encourage self-control, why does he embrace the provocation defense precisely when it does reward defendants' lack of control? ${ }^{106}$

Perhaps Wilson should not be blamed for this omission-accounts of the abuse excuse have typically ignored or misunderstood the provocation cases. ${ }^{107}$ And, although feminists have long decried the defense, sustained analysis at a theoretical and empirical level has only recently emerged. ${ }^{108}$ The problem is that Wilson seems both to know something about the provocation defense and to approve of it. Indeed, he specifically tells us that murder law should define manslaughter as a killing that "was the result of provocation, defined as behavior that would make a reasonable person immediately lose self-control."109 In the cases I described earlier, however, that was precisely the defendants' claim. ${ }^{110}$

105. My claim is not that the provocation defense is inherently male. My claim is that when the defendants likely to raise a particular defense are predominantly male, an intellectual method that requires us to excuse based on descriptions of the defendants will necessarily render the defense "male." See Nourse, supra note 9, at 1387. Not surprisingly, one does not have to be a feminist to see this. See Joshua Dressler, When "Heterosexual" Men Kill "Homosexual" Men: Reflections on Provocation Law, Sexual Advances, and the "Reasonable Man" Standard, 85 J. CRIM. L. \& CRIMINOLOGY 726, 735 (1995) (arguing that the provocation defense is "a male-oriented doctrine").

106. At one point, Wilson mentions two claims that women "provoked" their own deaths at the hands of husbands or lovers, but he makes no connection between these cases and the provocation defense. See p. 69.

107. Professor Dershowitz mentions provocation as a possible source of abuse but does not emphasize the claims of the rejected or betrayed man. See DERSHOwITZ, supra note 2, at 10-11 (noting "crime of passion" mitigation as an excuse commonly invoked by a spurned lover, but using the Lorena Bobbitt case as the prime example of potential abuse); see also id. at 137-39 (discussing provocation cases outside the context of spousal homicide).

108. See Kahan \& Nussbaum, supra note 9, at 305-23; Nourse, supra note 9, at 1340-56.

109. P. 103. Wilson might argue that the Peacock and Dixon cases are examples of situations in which the defendants waited too long so that their emotion was not sufficiently immediate to qualify as a plausible provocation claim. This assumes a particular and controversial legal proposition-that provocation claims are always limited to cases of immediate emotional outbursts. More importantly, it does not answer the essential question of why defendants are ever permitted to claim a partial excuse based on emotional rejection. Would Wilson embrace, for example, the defendant who reached the jury on manslaughter by arguing that he immediately lost control when his date "turned her back on him and went to sleep" after sex? People v. Wood, 568 N.Y.S.2d 651, 652 (App. Div. 1991), aff'd, 591 N.E.2d 1178 (N.Y. 1992).

110. Wilson might argue that, like imperfect self-defense claims, the provocation cases I have cited involve a failure to apply an objective, reasonable person standard. Even the most liberal versions of the defense, including MPC section 210.3 (extreme emotional distress), require a finding that the defendant had a "reasonable explanation or excuse." MODEL PENAL CODE $\S 210.3$ (1980). This requirement distinguishes the provocation defense from claims of diminished capacity and establishes it as "an outgrowth of the "heat of passion"" doctrine. Wood, 568 N.Y.S.2d at 653. 
The provocation cases not only cast doubt on the consistency of Wilson's claims, they also expose a commonly mistaken assumption about the proper villains in the abuse excuse drama. Professors Wilson and Dershowitz both suggest, obliquely at times and overtly at others, that women's claims have helped to promote abuse excuses. ${ }^{111}$ Wilson devotes more pages to battered women's syndrome than any other defense. ${ }^{112}$ Indeed, he organizes his treatment of the defense in such a way as to suggest, contrary to historical fact, that battered women's syndrome led to a general expansion of criminal law defenses under the rubric of "imperfect self-defense."113 In this way, he implies a slippery slope from Judy Norman all the way to the Menendez brothers. ${ }^{114}$

Indeed, Wilson finds it hard to refrain from sensationalizing the role of gender, despite expressions of sympathy for female victims. Wilson repeatedly uses women's claims to dramatize the failures of the system: Throughout the book, we are treated to accounts of baby-bashing mothers, PMSprone recidivists, and battered women who "assassinate" their husbands. ${ }^{115}$ But what of the men who kill their sleeping wives? ${ }^{116}$ If one is going to discuss intimate "execution[s]," 117 what about the numerous cases in which men pursue and kill wives who are trying to leave them? ${ }^{118}$ To emphasize cases

111. See pp. 44-58 (conflating self-defense claims like the Menendez brothers' with battered women's claims); pp. 66-67 (suggesting the development of the "battered person" syndrome from the "battered women's syndrome"); see also DERSHOWITZ, supra note 2, at 45 (stating that the abuse excuse "all began with the so-called battered woman syndrome").

112. See pp. 48-58, 101-02; see also pp. 62-66, 67-68, 96 (criticizing battered women's imperfect self-defense claims and battered women's syndrome). Battered women's claims are also mentioned throughout the book in the context of more general discussions. See, e.g., pp. 15-16 (criticizing battered women's syndrome as irrelevant to the facts of particular cases); p. 104 (arguing that a legislature's adoption of battered women's syndrome as proven is "bizarre"); p. 106 (criticizing courts for reversing convictions for failure to admit evidence, such as battered women's syndrome, when the error, if any, was essentially harmless).

113. Pp. 44-48 ( "[T]he plight of battered women has had a profound effect on criminal defenses."). The theory undergirding contemporary expansions of liability is far older than the claims of battered women. See Jerome Michael \& Herbert Wechsler, A Rationale of the Law of Homicide II, 37 COLUM. L. REV. 1261, 1280-81 (1937) (laying the theoretical groundwork for what would become the "extreme emotional disturbance" defense.). Similarly, the growth of expert testimony and mental impairment defenses is far from a recent development. See Schulhofer, supra note 3, at 850 (noting that the elements supporting the growth of expert testimony "were well in place in the 1950s, when mental impairment defenses expanded, and in the 1970s, when the opposite trend prevailed").

114. See pp. 44-69.

115. See pp. 33-36, 65; see also note 28 supra (quoting Wilson on these topics).

116. See, e.g., State v. Schmit, 329 N.W.2d 56, 56 (Minn. 1983) (describing how, after an argument, the defendant killed his wife while she slept and the jury returned a heat-of-passion manslaughter verdict).

117. P. 65 .

118. See, e.g, State v. Hull, 556 A.2d 154, 157, 165 (Conn. 1989) (describing how the defendant pursued and killed his wife, who had left him); State v. Wille, 839 P.2d 712, 713-14 (Or. Ct. App. 
involving battered women who kill their partners in fear without even mentioning cases involving men who kill their partners in anger seems almost calculated to distort.

Portraying women as the villains in the abuse excuse drama ignores important parallels in the legal doctrines governing men and women who kill their spouses. For example, Wilson and others have criticized battered women's syndrome for failing to treat women as moral agents. ${ }^{119}$ But this is nothing new: Men have claimed for decades that they should be partially excused from spousal homicide when their emotions get the better of them. ${ }^{120}$ Few scholars, however, have urged that we eliminate the provocation defense because it diminishes men's moral agency. ${ }^{121}$ Similarly, while battered women's self-defense claims have increased in scope and intensity in the past two decades, the same is true of men's provocation claims. While men's provocation claims used to focus on a wife's adultery, today's allegations may as easily depend on far more attenuated claims - that the defendant became upset when his partner moved the furniture out, took the kids, or argued about a messy house. ${ }^{122}$

At the same time, there are real differences in these cases: Whereas men's claims of provoked distress may be triggered by lawful and protected rejections (e.g., filing for a divorce), women's claims of self-defense are typically triggered by something the law unequivocally condemns (i.e., violence). ${ }^{123}$ As a result, the combination of these doctrines can, in some juris-

1992) (describing how the defendant, who was "very upset that his wife had filed" for divorce, killed her).

119. See p. 58; see also Anne M. Coughlin, Excusing Women, 82 CAL. L. REV. 1, 5-7 (1994) (arguing that the battered women's syndrome defense rests on a view that women lack a capacity for rational self-control).

120. Indeed, such arguments have not been limited to cases of murder but have been applied to other cases of intimate violence. See SUSAN ESTRICH, REAL RAPE 103 (1987) (citing People $v$. Gauntlett, 352 N.W.2d 310, 313 (Mich. Ct. App. 1984), for the proposition that judges have explained rape in terms of male defendants who had let their feelings "get out of hand").

121. Cf. Nourse, supra note 9 , at 1336 (noting that, under contemporary provocation law, " $[\mathrm{t}] \mathrm{o}$ obtain the law's compassion, men must ... play the role of the helpless female: dependent, victimized by inarticulate impulse, and utterly incapable of freely determining a proper course of action").

122. See State v. Reams, 616 P.2d 498, 499-500 (Or. Ct. App. 1980) (reporting that the defendant relied upon the provocation defense in a case in which he had murdered his father-in-law, claiming he snapped when his wife moved furniture out), aff'd in part and remanded, 636 P.2d 913 (Or. 1981); State v. Fair, 496 A.2d 461, 462-63 (Conn. 1985) (reporting that the defendant relied upon the extreme emotional disturbance defense to a murder charge by claiming he was upset after his exgirlfriend moved and told him he "would never see their son again"); State v. Werman, 388 N.W.2d 748, 749-50 (Minn. Ct. App. 1986) (reporting that the jury was instructed on the heat-of-passion provocation defense in a case in which the parties had argued over a messy house).

123. The precise sex distribution of intimate homicide remains somewhat unclear, but there is little doubt that men and women kill their intimate partners in different circumstances. Men are more likely than women to kill in situations where their partners have left or betrayed them, whereas women 
dictions, lead to a cruel dilemma for the battered woman: If she leaves and is killed, the law may say that the very act of leaving provoked her killer's distress. But if she acts on her own fears and kills, the law may question her claim for compassion precisely because she did not leave.

By focusing a tremendous amount of energy on battered women and associated "female" excuses, Wilson simply echoes a theme found in much of the literature-that social movements like feminism are responsible for the abuse excuse. "[E]mpathy for some group of disadvantaged defendants,"124 however, cannot explain the provocation cases. I am aware of no "bleeding heart" social movement seeking to advance the social cause of rejected men. Indeed, Wilson's accusation that social movements have influenced judges to view some defendants with leniency ${ }^{125}$ does not even hold true for his own examples. As far as I know, no social groups are out promoting group drunkenness, yet intoxication is one of Wilson's prime examples of abuse..$^{126}$ Victimology and the culture of complaint may be a convenient explanation, but if we are looking for abusive excuses we must look further than the usual suspects.

The truth is that if Wilson were to apply his theory consistently he would be forced to acknowledge that the abuse excuse is an empty idea. If, as he urges, the problem is the use of behavioristic causal explanation, then-as the provocation cases make clear-any excuse adopting that intellectual approach, traditional or not, can become an abuse excuse. This is not simply a

are more likely than men to kill in situations precipitated by violence. See Angela Browne \& Kirk R. Williams, Exploring the Effect of Resource Availability and the Likelihood of Female-Perpetrated Homicides, 23 L. \& SOC'Y REV. 75, 76 (1989) (citing studies finding that "female-perpetrated partner homicides are much more likely to be in self-defense . . . than are male-perpetrated homicides"); Margo Wilson \& Martin Daly, Spousal Homicide Risk and Estrangement, 8 VIOLENCE \& VICTIMS 3, 11 (1993) (noting that "a large majority" of spousal homicide cases were "precipitated by the husband's accusing the wife of sexual infidelity and/or by her decision to terminate the relationship"); see also Patrick A. Langan \& JOHN M. Dawson, U.S. Dep'T OF Justice, Spouse MURDer DEFENDANTS IN LARGE URBAN COUNTIES iv (Sept. 1995) (stating that in $44 \%$ of the spousal murder cases studied, women killed men at or about the time of a physical assault, as compared to $10 \%$ of cases studied in which men killed women at or about time of a physical assault); Wilson \& Daly, supra, at 4-8 (showing, based on data from several countries, that "wives are much more likely to be slain by their husbands when separated from them than when coresiding"). Given this, it should be perfectly understandable that male spouse killers, on average, receive higher sentences than female ones; if women are killing in self-defense they should be acquitted or receive lighter sentences than men who kill the women who leave them. This understanding, however, is vigorously disputed by abuse excuse enthusiasts. See DERSHOwITZ, supra note 2, at 312-13 (arguing that female spouse killers are treated more leniently than male spouse killers without acknowledging the difference in circumstances prompting the violence).

124. P. 112.

125. See p. 89 ("When the condition has acquired the status of a socially defined problem rather than the claim of an unattractive defendant, a judge will yield ground.").

126. See pp. 28-33. 
cute intellectual point-it is essential to understanding the nature of the debate about the abuse excuse. Wilson clearly believes that we can surgically remove the abusive excuses, leaving other traditional excuses safe from harm's way. But if the abuse excuse is not a set of excuses but a symptom of a disintegrating theory of excuse based on self-control, then Wilson cannot safely squirrel away some self-control based excuses and reject others. If the problem is that " $[t]$ he law has encouraged the explanatory rather than the judgmental mode of thought," 127 as Wilson asserts, then it is as much a problem with the provocation defense, duress, and other traditional excuses based on self-control as it is for the claims of battered women and intoxicated men. Wilson, however, is strangely unwilling to accept the implications of his emphasis on judgment. He clings to the idea that some traditional defenses should exculpate because the defendant lacks self-control while condemning the law's failure to encourage self-control in other excuses. In the end, Wilson applies his own theory of judgment selectively, leaving us to wonder, once again, how we are to know the real abuse excuse.

\section{EXPLANATION AND JUDGMENT}

All of this brings us to the ultimate theoretical question: Can Wilson's model of judgment save us from the abuse excuse? Wilson's principal aim is to tie his account of the abuse excuse to his more general musings about moral judgment. In this Part, I consider what Wilson means by judgment, discussing three possible models: judgment as community, judgment as character, and judgment as critique. In the course of this examination, I consider Wilson's claims in light of the new normativity in criminal law scholarship and its implications for arguments about the abuse excuse.

\section{A. The New Normativity}

Wilson is not the first scholar to emphasize the role of judgment in considering criminal law defenses. Recently, several apparently unrelated works have all relied upon the evaluative voice in critiquing particular doctrinesfrom heat of passion claims to race-based defenses to the voluntary act requirement. ${ }^{128}$ In the most comprehensive work to date, Professors Dan Kahan and Martha Nussbaum have argued, for example, that criminal law de-

127. P. 109.

128. See, e.g., Nourse, supra note 9, at 1374-80 (discussing the normative basis of the provocation defense); Armour, supra note 9, at 787-90 (arguing that self-defense claims based on racial fear expose the reasonable person as a normative ideal); Kahan \& Nussbaum, supra note 9, at 338-41 (suggesting an evaluative understanding of the voluntary act requirement, which dictates that a defendant not be held liable unless he acted voluntarily). 
fenses of all kinds-including duress, provocation, and self-defense-have always struggled with two different understandings, one they term "mechanistic" and the other "evaluative." 29 Although their work focuses on the role of emotion in criminal law, Kahan and Nussbaum, like Wilson, favor judgment, arguing that our criminal law defenses cannot be explained unless we acknowledge that the law does, and should, evaluate defendants' actions and reasons. ${ }^{130}$

The first and most obvious question this scholarly convergence raises is whether the new interest in judgment and evaluation is simply a matter of politics - a conservative backlash against a reigning liberal orthodoxy. There are good reasons to believe, however, that more is at stake here than the standard political arguments. The choice to embrace evaluation is not inherently conservative. Indeed, scholarly works to date have tended to suggest that normative reconstruction may be essential to claims typically associated with liberal positions. For example, judgment has been invoked as a means to assert racial and gender equality, ${ }^{131}$ to support the claims of battered women and reject the claims of provoked men, ${ }^{132}$ and to analyze claims with no apparent political bent, like the voluntary act requirement. ${ }^{133}$

That such diverse viewpoints might support the evaluative voice raises important questions about the meaning of the new normativity. Why are we seeing a convergence from such dissimilar quarters? And what does this tell us about the abuse excuse controversy? To try to answer these questions, I first turn to a more basic question-the nature of judgment itself.

129. See Kahan \& Nussbaum, supra note 9 , at $277-78$ (explaining the basic distinction between the mechanistic and evaluative views). For a more detailed description of the mechanistic view, see id. at 278-84; for the evaluative view, see id. at 285-301. Kahan and Nussbaum dedicate roughly half their article to describing how certain criminal law defenses are based on mechanistic or evaluative concepts. See id. at 301-50.

130. See id. at 350 (adopting an evaluative conception of emotion as "true" and proposing to provide "an independent normative defense" of its use in the criminal law).

131. See Armour, supra note 9, at 785 (arguing, based on a normative theory of reasonableness, that "courts must refuse to allow race-based claims of reasonableness . . . to figure in self-defense cases"); Nourse, supra note 9, at 1336-38 (arguing that the provocation defense is inherently normative and, once so understood, reveals the law embracing biases about men, women, and their relationships).

132. See Kahan \& Nussbaum, supra note 9, at 332-33 (urging a relaxation of the imminence requirement in battered women's self-defense cases based on an evaluative conception of the defense); Nourse, supra note 9, at 1396-97 (arguing that the provocation defense should not be available when the provocative act is legally protected or generally unpunished, based on a normative reconstruction of the provocation defense).

133. See Kahan \& Nussbaum, supra note 9, at 338-41 (arguing that evaluation is central to determining what the law considers a voluntary act). 


\section{B. Judgment as Community}

For the past fifty years, the standard liberal understanding of criminal law defenses has proceeded quite comfortably within the normative skepticism of the age. Believing that normative judgments are simply "valuechoices," 134 most criminal law theorists have stayed close to the behavioral aspects of crime. The resurgence in republican theory, ${ }^{135}$ however, has brought with it scholarly attempts to revive judgment as a focus of the criminal law. Kyron Huigens, writing in the Harvard Law Review, has urged scholars to recognize a republican theory of "inculpation," one in which criminal defendants are seen as judging beings whose judgments are measured by the practical wisdom of the community, represented by juries. ${ }^{136} \mathrm{~A}$ similar theme, with a similar fondness for classical influences, has been prominently displayed in important work by Kahan and Nussbaum. ${ }^{137}$

The republican notion of inculpation and excuse relies upon the idea that individuals should be judged by the quality of their choices, not simply their capacity for choice. Under this theory, we punish people by examining their exercise of practical judgment: "The factfinder, in deciding the case, will accept or reject the decision the actor made in the circumstances she faced; and in doing so, will pass judgment, ultimately, on the practical reasoning of that actor."138 Republican theory differs sharply from traditional liberal ideals of punishment and excuse because it posits the possibility of "the good," rather than neutrality among visions of the good.139 It emphasizes that

134. When we say that "normative questions" are values, we assume that norms are commodities, objects with certain attributes. Such an understanding loses the sense in which norms are commitments we make to one another in the vast uncertainty of the present about what will happen in the future.

135. The term "republican theory" is used to refer to a communitarian ideal, based not on the accumulation of individual desires, but on a shared fate and a shared sense of humanity. See Huigens, supra note 9, at 1456-57 \& n.133.

136. See Huigens, supra note 9, at 1458-67.

137. Kahan and Nussbaum argue for an evaluative conception of criminal law defenses based on the classical assumption that we are responsible for our characters and that we judge character, as did Aristotle, "by asking what a person of practical wisdom would do and feel in the situation." Kahan \& Nussbaum, supra note 9, at 287. Their reliance on Aristotle, however, is not exclusive. See id. at 288 (noting that Adam Smith also adhered to an evaluative conception in positing an "ideally reasonable person").

138. Huigens, supra note 9, at 1439; cf. Kahan \& Nussbaum, supra note 9, at 304-05 (noting that the "evaluative" view that they advocate "does not assert that appraising the quality of offenders" emotions is the only object of criminal law or that individuals must invariably be punished or condemned whenever they experience morally inappropriate emotions" or make bad judgments).

139. See Huigens, supra note 9, at 1457 . According to Huigens, republican theory

supposes there is an end, a purpose, a greater good served by political association. ... Whereas liberalism takes the good to be the aggregate of individual preferences or concerns itself with the 
"[w]e care about the quality of the accused's practical judgment" because this faculty allows the accused to "participate[] with us in the conduct and construction of our shared political life."140 According to republican theory, the community's shared moral understanding will, ultimately, shape the ways in which the defendant is judged. ${ }^{141}$

Although Wilson often seems deliberately vague about his idea of judgment, it is tempting to place him firmly in the republican camp. For example, he frequently equates judgment with the "commonsense view"142 or "shared moral sentiments of the people,"143 implying that all we must do to judge accurately and effectively is find the values that the community shares. It is clear, however, that Wilson is far from a complete devotee of community as the repository of all judgment; indeed, his embrace of the community turns out to be quite selective. For example, Wilson rejects as absurd the vast legislative and judicial support for battered women's syndrome, implying that sometimes the community is wrong. ${ }^{144}$ More importantly, he is willing to jettison the idea of judgment when it comes to some excuses but not others. While the defendant who claims duress should be able to argue that he lacked self-control, the defendant who claims intoxication, battered women's syndrome, or imperfect self-defense should be barred from making such claims. Why? Because Wilson is willing to embrace behavioristic arguments for some defendants but not others. ${ }^{145}$

distribution of primary goods and a fair opportunity to pursue one's own idea of the good, republican theory posits a greater good that transcends and comprehends individual preferences.

Id. (footnote omitted).

140. Id. at 1445 .

141. See id. at 1462-63. Huigens writes:

In deliberating, each juror decides, ultimately, whether she would have acted in the same way as the accused under the given circumstances. That decision is a collaborative one: the point of assembling a jury is to check the possibly biased, possibly idiosyncratic, possibly arbitrary judgments of an individual decision maker, with a view to approximating the community's judgment about the good of all.

Id. at 1463. Kahan and Nussbaum put their approach slightly differently, emphasizing the role of character, albeit recognizing that character is shaped by community standards. See Kahan \& Nussbaum, supra note 9, at 366 (noting that an evaluative conception "demands of people not only that they conform their conduct to a certain standard, but also that they shape their characters, and the quality of their emotions, in accordance with prevailing norms of reasonableness").

142. P. 37.

143. P. 111.

144. See pp. 54-56.

145. Wilson argues, for example, that "[b]eing under threat of death or grave bodily injury" makes an act "involuntary"- - a condition that "will excuse an otherwise criminal act." P. 42. This volitional understanding of duress and self-defense is quite common. See, e.g., Kahan \& Nussbaum, supra note 9, at 328-29, 334 (describing "voluntarist" understandings of self-defense and duress). On the other hand, I believe it runs contrary to Wilson's desire for a judgmental approach toward criminal law defenses. 
This selectivity suggests an important difference between Wilson's work and works advocating a republican theory of excuse or inculpation. Coherent communitarian claims do not stop at the use of "strong evaluation"146 to assess some claims and not others. Those who have urged the importance of strong evaluation, for example, have been insistent that we cannot pick and choose between behavioristic explanations in some cases and evaluative ones in others. As Charles Taylor explains, "[T] he vocabularies we need to explain human thought, action, [or] feeling . . . all inescapably rely on strong evaluation. Or put negatively, ... the attempt to separate out a language of neutral description . . . leads to failure." 147

Herein lies a distinction important to understanding Wilson's idea of judgment. At least on the surface, Wilson's idea of judging is similar to that propounded by others - he claims that it is not enough to explain defendants' actions; we must also critically evaluate their actions. When Wilson applies this understanding, however, he reaches results quite different from those of other scholars. For example, Wilson is extremely critical of battered women's self-defense claims, while Kahan and Nussbaum, who share his enthusiasm for the evaluative, argue that these claims may embody an appropriate evaluative ideal. ${ }^{148}$ Similarly, while Wilson suggests that if one is to accept battered women's claims of terror one must also embrace Bernhard Goetz's racial fears, ${ }^{149}$ Kahan and Nussbaum reach the opposite conclusion. They argue that the equation of battered women's fears with Goetz's racism misunderstands the evaluative concerns at stake. ${ }^{150}$

This disagreement betrays something very important about Wilson's idea of judgment. For Kahan and Nussbaum, it is not enough simply to segregate some defenses as evaluative and others as mechanistic - there are elements of these kinds of explanation throughout the criminal law and in defenses, new and old. ${ }^{151}$ For Wilson, however, judgment is something quite differ-

146. Charles Taylor, Philosophical ARguments 39 (1995).

147. Id. Taylor maintains that the case for this approach "has been convincingly made out, in a host of places." Id. at $39 \& 292 \mathrm{n} .7$ (citing sources supporting this position).

148. See Kahan \& Nussbaum, supra note 9, at 332-33 (suggesting an evaluative conception of the imminence requirement that does not depend on the destruction of battered women's agency); see also text accompanying notes 186-189 infra (discussing their argument at greater length).

149. See pp. 59-63.

150. See Kahan \& Nussbaum, supra note 9, at 332 ("An evaluative account of the battered woman's fear also explains why acknowledging her self-defense claim does not entail acknowledging the claims of offenders who, like Goetz, are impelled to violence by intense but morally inappropriate emotions."). Kahan and Nussbaum also argue that "[r]ecognizing battered woman syndrome does not require recognizing 'battered subway commuter syndrome' or other asserted conditions that rest on inappropriately low valuations of the lives or behavior of nonculpable victims." Id. at 365.

151. See id. at 301-05 (contrasting evaluative and mechanistic conceptions in criminal law generally); id. at $305-46$ (describing evaluative and mechanistic conceptions of the provocation, selfdefense, duress, voluntary act, and insanity defenses). 
ent-it inheres in particular excuses. Indeed, this is how Wilson defines the difference between judgment and explanation:

When a jury judges a defendant, it considers his or her mental state only to the extent necessary to establish the existence of one or another of a small list of excusing or justifying defenses, such as insanity, necessity, or self-defense. But when a jury explains the defendant's actions, it searches for a full account of the factors - the motives, circumstances, and beliefs - that caused them. ${ }^{152}$

Judgment, to Wilson, means a small list of traditional excuses, while to Kahan and Nussbaum it means an intellectual approach toward all excuses.

In the end, Wilson's judgment reduces to a claim of tradition for tradition's sake. His book is the perfect example of what Stephen Holmes calls "deprivation history."153 Wilson's premise is that we live in a world in which we have lost judgment and must regain it. This leaves in place the traditional excuses, subjecting only their more modern variants to negative judgments. Enamored by tradition, Wilson fails to see that there is another, equally plausible tale that might be told about judgment - that law has always exercised judgment, it simply has lost the ability to see that this is what it is doing. This is the kind of argument Professors Kahan and Nussbaum urge, a theory that does not limit evaluative claims to a particular time or place but seeks to unearth judgments hidden behind behaviorist trappings, whenever they may appear. Wilson, however, is only willing to judge in one direction, headed toward the past. If this is common sense, then it is a particular kind-what is common turns out to be what is well-established and, if this is judgment, then it is a particular kind-judgment as history. ${ }^{154}$

\section{Judgment as Character}

Were he to elaborate, Wilson might counter that, if his theory of judgment is traditional, its traditional focus rests soundly on the Aristotelian idea of "judgment as character." 155 One of Wilson's claims, in the chapter on self-defense, is that we have lost the idea of the "reasonable person."156 To-

\section{P. 90.}

153. STEPHEN Holmes, The ANATOMY OF ANTILIBERALISM 177 (1993) ("Communitarians ... [who] locate community in the past ... write deprivation history, wringing their hands about the world we have lost.").

154. Not surprisingly, Wilson's final words call for the "steady, lasting confines of a moral and legal order." P. 112.

155. See Huigens, supra note 9, at 1463 ("If, with Aristotle, we take judgment to be the prime constituent of character, inculpation is, as we have long suspected, a decision about character."); see also Kahan \& Nussbaum, supra note 9, at 299 ("Partisans of the evaluative conception . . . hold that individuals should in general be held responsible for their character, including its emotional elements ...."); see id. at 287 (explicitly linking this idea to Aristotle).

156. See pp. 59-63, 67-69 (decrying imperfect self-defense claims as personalized and subjectified). 
day, defenses have become so subjectified that juries are tempted to judge defendants by their self-description rather than by a common standard. ${ }^{157}$ Can an understanding of judgment as character solve this problem and provide a dividing line that is more than a restatement of tradition?

There is no question that republican theories of judgment rely heavily on the notion of character. As one author has explained,

[I]nculpation, as an inquiry into a person's relation to and responsibility for the greater good, is an inquiry into the person's character-more particularly into the soundness, maturity, and breadth of her practical judgment, the faculty by which she assembles her conception of the good and her scheme of ends. ${ }^{158}$

This idea of character is grounded in Aristotelian ideals. ${ }^{159}$ Character is not simply prudence or wisdom but the sum total of activities known as practical judgment. ${ }^{160}$ Thus, "I am responsible for my character to the extent I am responsible for the decisions I make about the ends and effects that shape it." 161

Can Wilson safely rely upon the reasonable man to establish judgment as character? There are several reasons to doubt whether this argument will satisfy either those committed to the Aristotelian model or those pursuing a consistent evaluative approach. First, the "reasonable man" is a figure of decided normative ambiguity in the law. Sometimes the term is used to mean the "good man"- what people should do-but it is also used to mean the "typical" man - what people actually do. ${ }^{162}$ Wilson never hints that he is disowning the latter, behavioral notion of the reasonable man; indeed his embrace of some defenses based on a lack of reasonable self-control suggests just the contrary. ${ }^{163}$ Second, Wilson's reasonable man is a far cry from the Aristotelian man of good character. In the Aristotelian tradition, character is firmly rooted in practical wisdom; it is neither rule nor standard. ${ }^{164}$ By contrast, Wilson's reasonable man seems premised on moral rule by consensus. ${ }^{165}$ Finally, even if Wilson's aim were to develop an evaluative theory without classical underpinnings, his emphasis on the reasonable person

157. See pp. 61-63.

158. Huigens, supra note 9 , at 1437-38.

159. See id. at 1426.

160. See id. at 1452-54 (explaining "Aristotle's [c]onception of [v]irtue"); id. at 1454-56 (explaining Aristotle's conception of deliberation and practical reasoning).

161. Id. at 1448 .

162. See Armour, supra note 9, at 787-90 (noting the tendency to equate the 'reasonableness' standard with typical or actual behavior). See generally George P. Fletcher, The Right and the Reasonable, 98 HARV. L. REV. 949 (1985).

163. See p. 103 (embracing provocation as a defense based on loss of self-control).

164. See Huigens, supra note 9, at 1462-63 (arguing that judgment in the Aristotelian sense "is, ultimately, not a matter of imposing a universal rule on a set of facts").

165. See text accompanying note 143 supra. 
would be problematic. As I have argued in another work, the very notion of the reasonable man undercuts the evaluative ideal. ${ }^{166}$ Analyses based on the reasonable man focus on individual persons and personality and, as such, on questions of identity: Who is the reasonable man and what characteristics does he have? ${ }^{167}$ By contrast, the evaluative ideal focuses on normative standards, standards which ask us to consider our relationship to each other rather than the characteristics of individuals. ${ }^{168}$

If all of this is right, then Wilson's attachment to the reasonable person cannot be attributed either to a search for a consistent evaluative ideal or to an Aristotelian belief in "judgment as character." Instead, context seems to suggest that Wilson values the reasonable person standard because it is associated with traditional doctrine - the traditional formulae of self-defense, provocation, and duress. Of course, the "reasonable man" formulation is not limited to traditional defenses. Indeed, defenses that Wilson would no doubt see as abusive are limited by reasonableness requirements. ${ }^{169}$ But in Wilson's lexicon, this appears to matter little. His judgment is, first and foremost, a judgment we have lost; judgment as history, not as character.

\section{Judgment As Critique}

This brings me to a competing model of judgment, one that sees judgment as critique. ${ }^{170}$ The beginnings of this idea were developed by the political philosopher Hannah Arendt. ${ }^{171}$ Arendt, like Wilson, saw a crisis of judgment in her own time. In the wake of the Eichmann trial, she argued that

166. See Nourse, supra note 9 , at $1384-89$.

167. See id. at 1384-85.

168. See id. at 1385-87. If Wilson's earlier book, The Moral Sense, is any indication, he wants to naturalize the idea of judgment within the reasonable person. See JAMES Q. WILSON, THE MORAL SENSE 2 (1993) ("The argument of this book is that people have a natural moral sense . ..."). This seems to me a proposal that would simply exacerbate the problems of behaviorism (or what Wilson calls the "explanatory mode," p. 109). See Nourse, supra note 9, at 1374-89 (arguing that naturalizing normative judgments in the minds of men does not help us resolve the debate about particular defenses; it simply makes the implicit normative claims invisible).

169. See MODEL PENAL CODE $\S 210.3$ (1980) (limiting the extreme emotional distress defense to a "reasonable explanation or excuse"); KENT GREENAWALT, LAW \& OBJECTIVITY 119 (1992) ("[T]he phrase 'reasonable explanation or excuse' envisions some moral judgment by the jurors about defendant's [sic] culpability.").

170. This is not to say that "common sense," interpreted as a public stance, is irrelevant to the concept of judgment. Such an idea may be necessary, however, without being sufficient.

171. Arendt "intended to complete her study of the life of the mind by devoting the third volume to the faculty of judgment, but was not able to do so because of her untimely death in 1975." MaURizio Passerin D'ENTREVES, The POlitical PhILOSOPHY OF HANNAH ARENDT 102 (1994). My discussion is based largely, but not exclusively, on her lectures on Kant's political philosophy. See HANNAH ARENDT, LECTURES ON KANT'S POLITICAL PHILOSOPHY (Ronald Beiner ed., 1982). 
far too many refused to judge. ${ }^{172}$ She decried "this atrophy of the faculty of judgment," finding it "precisely what had made Eichmann's monstrous crimes possible in the first place." 173 Here, however, Arendt's analysis departs sharply from Wilson's. The point, according to Arendt, is not to bury one's head in a search for a brighter, more judgmental past but to "judg[e] anew."174

What would this new beginning look like? Arendt argues, and rightly so, that "judgment can function only where those judged are neither beasts nor angels but men." 175 The danger of mechanistic theories is that they require us to believe that men are beasts driven by reasonless impulse. The danger of character theories is that they ask us to aspire to standards of angelic perfection. Arendt suggests that this dilemma can be resolved by critical reflection: "[E]ven the judge who condemns a murderer can still say when he goes home: "And there, but for the grace of God, go I."'176 This is a judge who condemns but does so warily, without certainty or joy, and with a humility that requires him not only to evaluate but also to identify with the defendant as a member of the human community. Judgment thus requires not only a critical faculty, but also the ability to imagine and identify with others with whom we disagree. ${ }^{177}$ It enjoins "us to make the effort to understand those whose point of view we not only do not share but may even find highly distasteful." 178

If judgment is to mean anything more than an unthinking acceptance of the status quo, it is essential that judgments be made with the fear and knowledge that they may be wrong. From this perspective, judgment is neither some vague brooding omnipresence, nor a vote count, nor a surrogate for traditionalism or community. Instead, judgment requires us to engage in an exercise of critical dialogue with possible interlocutors. Arendt calls this "representative thinking," or "thinking in the place of everybody else."179

I form an opinion by considering a given issue from different viewpoints, by making present to my mind the standpoints of those who are absent; that is, I represent them .... [T]his is a question neither of empathy, as though I tried to

172. See Ronald Beiner, Hannah Arendt on Judging, in LECTURES ON KANT's POLITICAL PHILOSOPHY, supra note 171, at 89, 99.

173. Id.

174. Id. at 98 (quoting Arendt).

175. Id.

176. Id. at 99 (quoting Arendt).

177. See id. at 102 (stating that the imagination enables us to "put ourselves in the minds of other men." (Arendt quoting Kant)).

178. Id. at 100 .

179. Id. at 104 (quoting Arendt). 
be or to feel like somebody else, nor of counting noses and joining a majority but of being and thinking in my own identity where actually I am not. ${ }^{180}$

The skeptic will reply that this is of no help at all. Representative thinking, like a focus on community or character, is equally indeterminate: How are we to know which representative judgment is right? A solution to this conundrum may be to synthesize this model with a more modest methodology associated with the republican ideal. ${ }^{181}$ Arendt's notion of a new beginning suggests that freedom impels us to start somewhere. Rather than seeking foundations, our beginning must start from the middle, from interlocutors who are embedded in particular situations and cultures. As Charles Taylor explains:

The task of reasoning, then, is not to disprove some radically opposed first premise (say killing people is no problem), but rather to show how the policy is unconscionable on premises which both sides accept, and cannot but accept. In this case, its job is to show up the special pleas. ${ }^{182}$

If there is one thing that binds the work of those engaged in what I term "judgment as critique," it is that their arguments seek to "show up the special pleas." Each begins from the middle, assuming a set of basic premises about the law. And each argues that these constructs-about which there is widespread agreement-mask implausible or incoherent normative claims. Consider, for example, the work of Professor Jody Armour. Armour asks why contemporary formulations of self-defense doctrine appear to permit the claims of the "reasonable racist"-the defendant who claims self-defense based on the belief that blacks are prone to violence. ${ }^{183}$ Armour argues that contemporary understandings permit such claims because they assume that the "reasonable man" is a standard of typicality rather than the expression of a moral norm. ${ }^{184}$ Ultimately, Armour argues that we should reject the claims of the "reasonable racist" because they are inconsistent with well-established constitutional principles commanding racial neutrality. ${ }^{185}$

180. Id. at 107 (quoting Arendt).

181. Arendt's theory of judgment is based largely on Kantian ideas. See Beiner, supra note 172, at 135-38, 140-41 (questioning why Arendt did not turn to Aristotle more fully in developing her theory of judgment); D'ENTREVES, supra note 171, at 132-35 (suggesting that Arendt's turn to Kant was a better alternative than a full embrace of Aristotelian ideals).

182. TAYLOR, supra note 146, at 36 . This kind of argument is consistent with both Kantian and communitarian positions. See Barbara Herman, The PRACTICE OF MORAL JUdGMENT 51 (1993) ("For Kant, the embeddedness of the person in the particular is the natural and necessary starting point of moral judgment ... The Kantian moral agent . . . comes to need a procedure for moral judgment when he is tempted to make an exception for himself from known moral precepts.").

183. See Armour, supra note 9, at 787-90.

184. See id. at 788.

185. See id. at 805-09. 
A similar kind of unmasking is suggested by Kahan and Nussbaum's treatment of battered women's self-defense claims. They argue that an evaluative approach should support a "relaxed" imminence requirement, ${ }^{186}$ not simply because this position reflects values of which they approve but because it is more coherent with existing law. "True man" and "castle" rules, they argue, protect the sense of honor and dignity that comes from confronting, rather than avoiding, violence. ${ }^{187}$ If the law is willing to relax the terms of the "imminence" requirement to protect the honor and dignity of the "true man" who holds his ground, Kahan and Nussbaum ask, then why is it not willing to relax that requirement when a battered woman's honor and dignity is at stake?188 It simply is not true, they urge, that "the law never ranks the defendant's honor and dignity over a wrongful aggressor's life." 189 If the law does so rank dignity and honor, to deny similar claims to battered women "betrays either extreme confusion or hypocrisy."190

Armour, Kahan, and Nussbaum would likely agree with Wilson that, to excuse, we must judge defendants' motives and reasoning. And, yet, it is also quite clear that Wilson's idea of judgment is markedly different. Armour, Kahan and Nussbaum use judgment as critique, unearthing evaluative claims from behaviorist trappings. They do not pick and choose defenses that reflect "judgment" and those that do not; they employ judgment as an intellectual method to explain and critique inconsistencies within contemporary doctrine. One of the great dangers of evaluative theories is that they simply reaffirm the valuations of those who create and apply them. Judgment as critique, however, does not appeal to an inarticulate or privileged sense of that which is "common"; it relies, instead, upon the law itself as the measure of what we share. Thus, Professor Armour argues that a law that rejects racial bias cannot consistently embrace the "reasonable racist"; similarly, Professors Kahan and Nussbaum argue that a law that embraces the

186. Kahan \& Nussbaum, supra note 9 , at 332.

187. See id. at 329 (describing the nineteenth century origins of the "true man" or "no retreat" doctrine, which allows a man to fight an attacker rather than retreat because a "true man" would be demeaned by fleeing); id. at 329-30 (explaining the "castle" rule as the doctrine that allows a person who is attacked in his house to use violence in defending his "castle" to "spare [him] the indignity" associated with flight from home).

188. See id. at 332-33. This is not the only argument about "imminence" that could be made from an evaluative perspective. One might claim, for example, that the imminence requirement serves to enforce the bargain between citizen and state: that the citizen may use self-help remedies when the state cannot possibly intervene in time. The imminence requirement, however, disappears in situations where, even with unlimited time, the state cannot possibly intervene to prevent a harm-for example in the cases of kidnapping victims or prisoners of war. A battered woman, having requested and been denied police protection, might well ask how the law may consistently forgive the imminence requirement when the law cannot act but impose it in cases where the law has refused to act.

189. Id. at 333 .

190. Id. 
honor of a "true man" cannot consistently reject claims of honor by battered women. These arguments begin "anew" by challenging orthodox positions, but they also begin "from the middle," demanding not that we resolve first premises about criminal defendants' identity, but that we proceed from the more modest position that a just criminal law must, at a minimum, make consistent evaluative claims.

\section{E. The Abuse Excuse and the Future of the New Normativity}

Once, there was a consensus within the legal academy that criminal law defenses were to be defined and limited by the idea of self-control. ${ }^{191}$ This consensus was so powerful that it shaped not only legal theory, but also newly emerging defenses. ${ }^{192}$ Logic foretold, however, that if this theory were to be pursued, difficulties would arise. Soon, real life seemed to provide confirmation: Defendants pushed the theory of self-control to its limits, making arguments that seemed to defy common sense and invite perverse results. ${ }^{193}$

If I am right that extensions of the theory of self-control have led us here, then the abuse excuse is more rhetorical creation than real crisis. Although particular defenses are more often abused than others, the problem does not lie in the development either of a special set of excuses or a particularly modern type of excuse. Rather, if the problem is a theory of excuse, we cannot confidently separate the "new" and "dangerous" excuses from the old "traditional" ones, as Wilson would have us do. The abuse excuse is everywhere the theory is and, therefore, nowhere.

From this perspective, it is no coincidence that the new normativity has arisen in the same era that produced criticism of the abuse excuse. Both movements are struggling with the implications of a mechanistic theory of excuse. The abuse excuse critique focuses on the "real life" consequences of the "new" defenses, highlighting cases in which the theory of self-control leads to absurd results. The new normativity focuses, by contrast, on the underlying theory of self-control, suggesting that we need to shift our focus from behavioral theories toward evaluative ones.

Will the new normativity replace the theory of self-control? It is far too early to tell, but there are reasons both for concern and hope. The new normativity raises obvious and important questions: How are we to know which

191. See note 73 supra and accompanying text.

192. For example, when battered women began to argue their cases, they reached out to the model of self-control, arguing that they had lost the ability to judge circumstances as others might. Soon, however, concerns arose that the plan had backfired by once again portraying women as "helpless females."

193. See note 80 supra and accompanying text. 
evaluations are "right"? And if we cannot discern the "right" evaluations, don't we risk forcing the morals of an intolerant community upon unsuspecting individuals? Wilson's theory raises both risks quite prominently. Although Wilson is confident that he can discern the good evaluations from the bad, his obvious selectivity is disconcerting. If, like Wilson, we simply pick and choose the defenses we like and call them evaluative or common sense, we risk making serious mistakes. As Wilson himself acknowledges, history warns that common sense may be terribly misguided. ${ }^{194}$ To assume that all the "bad" common sense can be safely relegated to the past-as Wilson appears to assume-risks not only complacency but folly.

If the new normativity suggests dangers in some forms, it also suggests opportunity in others. For decades, criminal law scholars have believed that the best defense against the claims of an intolerant community is a law of excuse that preserves a sphere of individual autonomy. Theory and experience, however, suggest that autonomy-based theories cannot prevent, and may even further, injustice. Are we really safe with contemporary theories when they permit the claims of reasonable racists, ${ }^{195}$ unabashed batterers, ${ }^{196}$ rejected lovers, ${ }^{197}$ and homophobic killers? ${ }^{198}$ One can as easily perpetuate injustice by deferring to an existing world of inequality as by imposing a norm of inequality. The only difference is that if one defers to the way things are, it becomes more difficult to see, name, or fight injustice. In its critical forms, the new normativity rejects the notion that safety for the individual lies in the ideal of a separate sphere. Indeed, it posits that the best defense against an oppressive norm is the ability to counter "bad" evaluative speech with "good" evaluative speech.

Theories of self-control have mired academics in frustrating and repetitive debates. Criminal law scholars have spent enormous amounts of time trying to answer fundamentally unanswerable questions about how the law should describe the "reasonable man of self-control"-whether the reason-

194. See p. 112 (conceding that for decades fact finders used their common sense to "extend[] boundless understanding to whites who lynched blacks").

195. See Armour, supra note 9, at 787-90 (showing how conventional doctrinal rules permit such claims).

196. See Nourse, supra note 9 , at 1354-55 (showing how conventional doctrinal rules permit defendants to claim their own bad acts-their own infidelity or battering-as an excusing feature). see also Newell v. State, No. 269, 1990, 1992 WL 53433, at *1-*2 (Del. Mar. 4, 1992) (describing how the defendant relied upon evidence of his own battering, to which he stipulated, to "develop his defense of extreme emotional distress").

197. See Nourse, supra note 9, at 1351-66 (describing how such cases arise under the modern provocation defense).

198. See, e.g., Kahan \& Nussbaum, supra note 9, at 359-62 (arguing that the current mechanistic theory would permit defendants to claim homophobia as an excusing feature since the mechanistic theory focuses on the intensity, rather that the quality, of emotion). 
able man should be the reasonable black man, or the reasonable blind man, or the reasonable woman. ${ }^{199}$ This, in turn, has frozen normative propositions in the descriptions of persons. The normative claim that a man is justified in killing his wife's lover becomes a claim of identity: that men are just 'that way,' that they naturally lose self-control in such situations. The new normativity, at least in its critical forms, challenges such understandings by seeking to dislodge evaluative claims from their descriptive premises. ${ }^{200}$

Wilson's own view of judgment is a testament to the fact that evaluative theories can embody partial or selective standards. But it is important to remember that the intellectual technique of evaluation does not always require the imposition of judgment from on high or from nowhere. The new use of judgment as critique seeks to expose inconsistencies within the criminal law itself. For example, it would not be enough under this view to argue that battered women's self-defense claims reflect correct judgments without also arguing that the failure to accept such testimony is in essence a "special plea." Kahan and Nussbaum, for example, do not simply assert that the evaluative view is better; they argue that rejecting the claims of battered women may be inconsistent with other uncontroversial commitments within the law of self-defense (specifically, true man and castle rules). ${ }^{201}$ This is a claim of coherence: It aims to persuade by proceeding from the "middle," from premises that are likely to be shared rather than from demands that first premises be resolved before we can address real-life dilemmas.

Future work will need to explore these theories in greater detail. Meanwhile, it is worth trying to put the claims of the abuse excuse in some perspective. Three short decades ago, Professor Herbert Packer reported that large-circulation magazines eagerly embraced as "standard fare" the slogans of a culturally popular behaviorism: "treat the criminal, not the crime," "punishment is obsolete," and "criminals are sick." 202 Today, cultural fears of moral relativism and victimology have led to new and different slogans: "personal responsibility," "self-control not sob-stories," and the "abuse excuse." Professor Wilson's book will no doubt help popularize these phrases

199. Casebooks, for example, frequently pose this question for students. See, e.g., JosHUA DRESSLER, CASES AND MATERIALS ON CRIMINAL LAW 232-33 (1994).

200. In some forms, the new normativity also seeks to dislodge the current focus on the defendant's characteristics or character by focusing on the relationship of the defendant to the victim. See Nourse, supra note 9, at 1375-80, 1384-87. If punishment seeks to "annul or counter the appearance of the wrongdoer's superiority and thus affirm the victim's real value," then defenses, to be plausible, must negate the defendant's claim of superiority vis-à-vis the victim. JEFFRIE G. MURPHY \& JEAN HAMPTON, FORGIVENESS AND MERCY 130 (1988). This is always, however, a relational matter, not one which can be answered outside the context of individual cases or without reference to the defendant's relationship to the victim.

201. See Kahan \& Nussbaum, supra note 9, at 329-33.

202. PACKER, supra note 73 , at 12. 
but one wonders whether, thirty years from now, these catchwords will seem as odd and extreme as the slogans of yesteryear. In the end, we might do better if we were to focus less on the abuse excuse and more on the theories that have led us there. 